\title{
Psychology
}

Books and Journals from Cambridge University Press

Cambridge University Press is a leading publisher in the psychological and brain sciences.

From undergraduate course resources, our prestigious Cambridge Handbooks in Psychology series, our leading journals including Behavioral and Brain Sciences and Development and Psychopathology, and our extensive collection of scholarly monographs.

Cambridge supports learning and research across all of psychology and related fields.

For further details visit:

cambridge.org/core-psychology

\section{Çambridge Core}




\section{Language and Linguistics \\ Books and Journals from Cambridge University Press}

We are the world's leading publisher in language and linguistics, with a wideranging list of journals and books covering the scope of this discipline.

Our publishing encompasses theoretical, applied and sociolinguistics, and represents a breadth of subfields, including grammar and syntax, phonetics and phonology, semantics and pragmatics, historical linguistics, discourse and conversation analysis, psycholinguistics and neurolinguistics, and first and second language acquisition.

Our acclaimed book list includes state-of-the-art monographs as well as major reference works, guides to research methods, and textbooks at all levels.

For further details visit:

cambridge.org/core-languare-and-linguistics

\section{Cambridge Core}


Research notes

642 Jennifer Menjivar and Nameera Akhtar. Language experience and preschoolers' foreign word learning

649 Marta Ramon-Casas, Christopher T. Fennell and Laura Bosch. Minimal-pair word learning by bilingual toddlers: the Catalan /e/-/ع/ contrast revisited

\section{SUBSCRIPTIONS}

Bilingualism: Language and Cognition (ISSN 1366-7289) is published five times a year in January, March, May, August and November. Five parts form a volume. The 2017 subscription price (excluding VAT) of a volume, which includes print and electronic access, is $£ 520$ (US $\$ 851$ in USA, Canada and Mexico); $£ 81$ (US \$131) for individuals, which includes print only, ordering direct from the publisher and certifying that the journal is for their personal use. The electronic-only price available to institutional subscribers is $£ 425$ (US \$714 in USA, Canada and Mexico). Single parts are $£ 120$ net (US $\$ 196$ in USA, Canada and Mexico) plus postage. EU subscribers (outside the UK) who are not registered for VAT should add VAT at their country's rate. VAT registered members should provide their VAT registration number. Japanese prices for institutions (including ASP delivery) are available from Kinokuniya Company Ltd, P.O. Box 55, Chitose, Tokyo 156, Japan. Orders, which may be accompanied by payment, may be sent to a bookseller, subscription agent or direct to the publisher, Cambridge University Press, Journals Fulfillment Department, UPH, Shaftesbury Road, Cambridge CB2 8BS, UK; or in the USA, Canada and Mexico: Cambridge University Press, 1 Liberty Plaza, Floor 20, New York, NY 10006, USA. Copies of the journal for subscribers in the USA are sent by air to New York to arrive with minimum delay.

\section{COPYING}

The journal is registered with the Copyright Clearance Centre, 222 Rosewood Drive, Danvers, MA 101923, USA. Organisations in the USA who are also registered with C.C.C. may therefore copy material (beyond the limits permitted by sections 107 and 108 of

U.S. copyright law) subject to payment to C.C.C. of the per-copy fee of $\$ 12.00$. This consent does not extend to multiple copying for promotional or commercial purposes. Code 1366-7289/2017/\$12.00.

ISI Tear Sheet Service, 3501 Market Street, Philadelphia, PA 19104, USA is authorized to supply single copies of separate articles for private use only.

Organisations authorized by the Copyright Licensing Agency may also copy material subject to the usual conditions.
For all other use, permission should be sought from Cambridge or from the American Branch of Cambridge University Press.

Information on Bilingualism: Language and Cognition and all other Cambridge journals can be accessed via http://www.cup.cam.ac.uk/ and in North America via http://www.cup.org/.

This journal issue has been printed on FSC-certified paper and cover board. FSC is an independent, non-governmental, not-for-profit organization established to promote the responsible management of the world's forests. Please see www.fsc.org for information. 


\section{B I LINGUALISM:}

\section{LANGUAGE AND COGNITION}

\section{CONTENTS}

\section{Research articles}

435 Sina Bosch, Helena Krause and Alina Leminen. The time-course of morphosyntactic and semantic priming in late bilinguals: A study of German adjectives

457 Seçkin Arslan, Dörte De Kok and Roelien Bastiaanse. Processing grammatical evidentiality and time reference in Turkish heritage and monolingual speakers

473 Peter Indefrey, Hülya Şahin and Marianne Gullberg. The expression of spatial relationships in Turkish-Dutch bilinguals

494 Oliver Boxell and Claudia Felser. Sensitivity to parasitic gaps inside subject islands in native and non-native sentence processing

512 Elena Shimanskaya and Roumyana Slabakova. Re-assembling objects: a new look at the L2 acquisition of pronominal clitics

530 Marc Brysbaert, Evelyne Lagrou and Michaël Stevens. Visual word recognition in a second language: A test of the lexical entrenchment hypothesis with lexical decision times

549 Xinxin Li, Carol Kit Sum To and Manwa Lawrence Ng. Effects of L1 tone on perception of L2 tone - a study of Mandarin tone learning by native Cantonese children

561 Liquan Liu and René Kager. Perception of tones by bilingual infants learning non-tone languages

576 Carlos Romero-Rivas, Joanna D. Corey, Xavier Garcia, Guillaume Thierry, Clara D. Martin and Albert Costa. World knowledge and novel information integration during L2 speech comprehension

588 Ellen Bialystok, Kornelia Hawrylewicz, Melody Wiseheart and Maggie Toplak. Interaction of bilingualism and Attention-Deficit/Hyperactivity Disorder in young adults

602 Lucy Kerrigan, Michael S. C. Thomas, Peter Bright and Roberto Filippi. Evidence of an advantage in visuo-spatial memory for bilingual compared to monolingual speakers

613 Klara Marton, Mira Goral, Luca Campanelli, Jungmee Yoon and Loraine K. Obler. Executive control mechanisms in bilingualism: Beyond speed of processing

632 Yeh-Zu Tzou, Jyotsna Vaid and Hsin-Chin Chen. Does formal training in translation/ interpreting affect translation strategy? Evidence from idiom translation 